\title{
ABOVE-GROUND AND SEED BANK WEED BIODIVERSITY COMPARISON IN CONVENTIONAL AND ORGANIC FARMING SYSTEMS IN POLAND
}

\author{
Adam Kleofas Berbeć, Beata Feledyn-Szewczyk \\ Institute of Soil Science and Plant Cultivation, State Research Institute in Puławy, Poland \\ aberbec@iung.pulawy.pl
}

\begin{abstract}
The assessment and conservation of agricultural biodiversity is one of the current goals of European Union policies, which is reflected in European Biodiversity Strategy. The biodiversity of soil seed bank and above-ground weed flora were investigated in spring cereals in organic and conventional farming system. The study was carried out between 2012 and 2014. Species of above-ground wild flora were counted on a surface of $1 \mathrm{~m}^{2}$ in the field. Soil for seed bank evaluation was taken from the field and evaluated by seedling emergence method in a greenhouse. There were no significant differences in number of species between two communities. Biodiversity of weed community, described by Shannon's diversity index and Simpson's dominance index, was significantly better maintained in the soil seed bank than in above-ground flora in both farming systems. A strong, positive correlation between the number of species, Shannon's diversity index, Simpson's dominance index of soil seed bank and above-ground weed species was found in both farming systems, while abundance of seeds and above-ground weeds was significantly, positively correlated only in the conventional farming system. Qualitative composition of weed flora depended more on the type of community (soil seed bank or above-ground weed communities) than the farming system.
\end{abstract}

Key words: weeds, soil seed bank, farming systems, segetal flora.

\section{Introduction}

Biological diversity of agricultural land is created by diversity of crops and accompanying wild plants (weeds), but also diversity of microorganisms, invertebrates and other organism, for which agricultural ecosystem creates an excellent living environment. A high biodiversity of agricultural land can be beneficial for farmers as it provides a number of ecosystem services which result in an increased stability of ecosystem and reduced costs of production due to lower demand for chemical plant protection products. Biodiversity conservation is one of the major objectives of the European Union policies, which is reflected in the European Biodiversity Strategy (European Commission, 2011). The strategy applies also to agricultural areas of Europe, where it aims at reducing the loss of biological diversity and linked ecosystem services. Sustainable, both highly efficient and environmentally friendly, agriculture cannot exist without a wide range of ecosystem services, which ensure high fertility of soils, proper water management, biological protection, nutrient cycles and a high productivity of agro-ecosystems (Clergue et al., 2005).

The soil seed bank is closely related to the actual weed infestation visible on the field surface. The population of many weed species consists to a greater extent of seeds present in the soil than from the plants present on the surface of fields (Harper, 1977). The total number of seeds in the soil, especially in the case of arable lands, is very large and can amount to several hundred thousand per square meter (Cavers, 1983; Pawłowski \& Wesołowski, 1980, 1989; Wojciechowski \& Sowiński, 2007). Thus, the soil seed bank is a reservoir that can restore populations of both short-lived and perennial weeds (Baker, 1989).
Soil seed bank is the beginning of the life cycle and the only way to preserve the continuity of the species for annual plants. Most of seeds in the soil die within the first few years, but seeds of some weed species can survive for several dozen years under appropriate conditions (Cavers, 1983). In addition, seeds present in the soil can remain viable even after a change in the type of use, for example after forest succession (Woch, 2012). Thus, the soil seed bank is a kind of 'memory' of the ecosystem, in which the seeds of the majority of the previously living species are contained. The soil seed bank may prove valuable also for farmers. For example, it could be very important when 'superweeds' occur on the field (weeds resistant to herbicides due to irrational use of herbicides). In this case, sensitive genotypes of plants stored in the soil seed bank should be allowed to germinate for a few years. Thanks to intra-species competitiveness, sensitive ecotypes will naturally supplant resistant ecotypes.

The aim of the study was to compare biological diversity of above ground and soil seed bank weed communities in two farming systems - organic and conventional.

\section{Materials and Methods}

The study was carried out in the years 2012-2014. Both above-ground and soil seed bank weed flora were investigated annually between $10^{\text {th }}$ of June and $5^{\text {th }}$ of July. The total sample size was 30 spring cereal fields cultivated under the conventional farming system conditions and other 30 spring cereal fields cultivated under organic farming. All fields were located in the Lubelskie region, one of the easternmost regions of Poland. All fields were located in the valleys of Wieprz, Tysmienica and Bug rivers, in the vicinity 
of NATURA 2000 areas. Most fields were located on light, sandy soils (most common in Poland).

Organic and conventional fields were chosen as pairs, to minimize the impact of the local soil and weather conditions. Above-ground weed flora species and their abundance were counted on a surface of 1 $\mathrm{m}^{2}$ on each field. There were 5 samples (replications) on each cereal field with $10 \mathrm{~m}$ spacing between the samples. Soil samples were collected from the direct vicinity of above-ground samples, with the soil cylinder of a $8 \mathrm{~cm}$ diameter (surface of about 50 $\mathrm{cm}^{2}$ ), from the soil layer of $0-20 \mathrm{~cm}$. Collected soil samples were placed in pots filled partially with sand (drainage). Emerging seeds were counted and assigned to the species during the 12-month exposition in the greenhouse (seedling emergence method).

The number of species, their abundance, Shannon's diversity index (H') and Simpson's dominance index (SI) were chosen as indicators describing biological diversity of both above-ground and soil seed bank weed communities. Spearman's correlation coefficient also was used to find the correlation between these two communities. As most of the biodiversity parameters were deviated from the normal distribution, the significance of differences was determined by Mood's test (comparison of medians) at a significance level of $\alpha=0.05$. Cluster analysis using Sorensen's similarity coefficients were used to assess the quantitative and qualitative similarity of the tested weed communities. The analysis was done by MVSP 3.1 Software.

\section{Results and Discussion}

\section{Number of species and their abundance}

In total, there were 165 weed species observed in both above-ground and soil seed bank weed flora during the 3-year study period (Table 1). One hundred fifty one species were found in the above-ground weed community, while 96 were found in the soil seed bank weed community. Eighty two species were common for both communities, while 69 species were found only in the above ground flora and other 14 only in the soil seed bank. Interestingly, when the organic and conventional farming systems were compared, it was visible that more unique species were observed for the soil seed bank of conventional farming system (38) than for organic farming system (17). This makes soil seed bank an important weed biodiversity reservoir, especially in the farming systems which are unfavourable for wild flora due to intensive weed management. In those systems, soil seed bank plays the role of 'agroecosystem memory'.

There were no statistically significant differences between the number of weed species in the aboveground flora and in soil seed bank, both in organic and in conventional farming system (Figure 1). According to the literature study, species composition of the above-ground weed flora is more susceptible to weather conditions and agrotechnical practices than weed community of soil seed bank. Hence, it is difficult to clearly describe the relationship between species composition of above-ground and the soil seed bank (Wesołowski, 1984; Zhang et al., 1998; FeledynSzewczyk, 2003; Rahman, James, \& Grbavac, 2006). Zhang et al. (1998) believe that there is no basis for determining the exact, quantitative and qualitative relationship between segetal flora on the field and the soil seed bank. This is due to the fact that only a small part of seeds find suitable conditions for germination under field crop conditions. As a result, the number of species observed in the above-ground weed flora is always lower than the actual number of species deposited as seeds in the soil. In addition, soil seed bank contains species from neighbouring phytocoenoses, which are not characteristic of agricultural ecosystems (Froud-Williams, Chancellor, \& Drennan, 1983). In the presented study, a trend has been observed that the number of species in the soil seed bank was slightly lower than in above-ground flora, but no significant differences were found. Vandvik et al. (2016), based on their own research and literature review, found that species composition of the current weed infestation is dependent on the species composition of the soil seed bank. The authors found that the species richness is always greater in the soil seed bank than in the above-ground weed flora, and any possible deviations from this rule result from the inaccuracy

Table 1

Total number of species (2012-2014) found in above-ground and soil seed bank weed flora in different farming systems

\begin{tabular}{|c|c|c|c|c|c|c|}
\hline \multirow{3}{*}{ Parameters } & \multicolumn{6}{|c|}{ Farming system and type of community } \\
\hline & \multicolumn{2}{|c|}{ Organic } & \multicolumn{2}{|c|}{ Conventional } & \multicolumn{2}{|c|}{ Organic + Conventional } \\
\hline & above-ground & seed bank & above-ground & seed bank & above-ground & seed bank \\
\hline Total species & 133 & 86 & 116 & 96 & 151 & 96 \\
\hline Unique species & 64 & 17 & 58 & 38 & 69 & 14 \\
\hline Common species & \multicolumn{2}{|c|}{69} & \multicolumn{2}{|c|}{58} & \multicolumn{2}{|c|}{82} \\
\hline Median weed density (plants $\mathrm{m}^{-2}$ ) & 297 & - & 170 & - & 233 & - \\
\hline Median seed density $\left(\right.$ seeds $\left.\mathrm{m}^{-2}\right)$ & - & 9300 & - & 5300 & - & 7300 \\
\hline
\end{tabular}




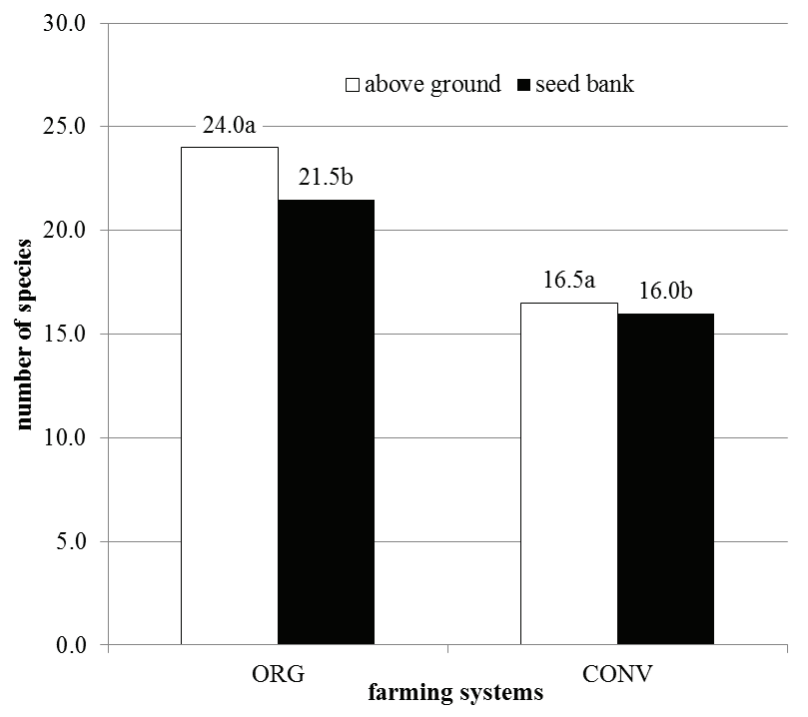

Figure 1. Average number of species of above-ground and soil seed bank weed communities (medians for the years 2012-2014).

a, b- different letters indicate statistically significant differences between soil seed bank and above-ground weed communities.

of the methods chosen for the assessment of the soil bank or/and above-ground seeds and flora. In the presented study, the number of above-ground species and their abundance were counted on a surface of 1 $\mathrm{m}^{2}$, while soil samples were taken from a surface of 50 $\mathrm{cm}^{2}$, which is 200 times smaller area. It is also worth mentioning that in the presented study the number of species was more stable and less susceptible to external disturbances in the soil seed bank than in above-ground weed flora community. The differences between different farming systems are mainly due to chemical weed management. Those management practices strongly decrease the population of sensitive species, while not affecting herbicide-resistant species (Turner et al., 2007; Graziani et al., 2012). Species of soil seed bank could also be affected by crop rotation. Organic farms usually have more complex crop rotations, which creates favorable conditions for various weeds to germinate, flower and release the seeds (Teasdale et al., 2004; Murphy et al., 2006; Graziani et al., 2012).

Shannon's diversity index ( $\left.H^{\prime}\right)$ and Simpson's dominance index (SI)

Shannon's diversity index indicated a high value of weed biodiversity for both weed communities in both farming systems. This index for the three-year study period for soil seed bank community reached significantly higher values than for the above-ground flora $\left(H^{\prime}=2.31\right.$ for soil seed bank versus $H^{\prime}=1.88$ for above ground flora for organic farming, and $H^{\prime}=1.92$ versus $H^{\prime}=1.60$ in conventional farming system, respectively) (Figure 2). Also Simpson's dominance index reached low values in both farming systems and in both weed communities, which again indicated a good biodiversity conservation status in the research area. Median values of Simpson's index (SI) for soil seed bank community were significantly lower than for above-ground flora in both farming systems $(\mathrm{SI}=1.88$ for soil seed bank versus $\mathrm{SI}=2.31$ for above ground flora for organic farming, and $\mathrm{SI}=1.60$ versus $\mathrm{SI}=1.92$ in conventional farming system, respectively), which confirmed that biodiversity of weeds in soil seed bank is less dominated by single species than community of above-ground flora (Figure 3). Feledyn-Szewczyk \& Duer (2007) found that values of Shannon's diversity indices were higher, while Simpson's dominance indices were lower for soil seed bank than for aboveground weed flora in most farming systems. Only the organic farming system had a similar biodiversity of the above-ground weed flora and soil seed bank weed flora. Authors also found that the range of values for Shannon's diversity indices and Simpson's dominance indices was more similar for soil seed bank than for above ground weed flora, which was also confirmed in the presented study. This proves the theory that the seed bank weed communities are more resistant to external disturbances. Chick et al. (2018) also found that both the soil seed bank and above ground vegetation can be affected by climatic factors, but species turnover of the above-ground communities is more likely to be also affected by the disturbance factors, while soil seed bank seems to be more resistant to those factors. The comparison of biodiversity of above-ground and soil seed bank community in subsequent study years of the presented study showed that soil seed bank was more stable over time, while above-ground weed flora was more susceptible to external disturbances. According to many authors, soil seed bank ensures 


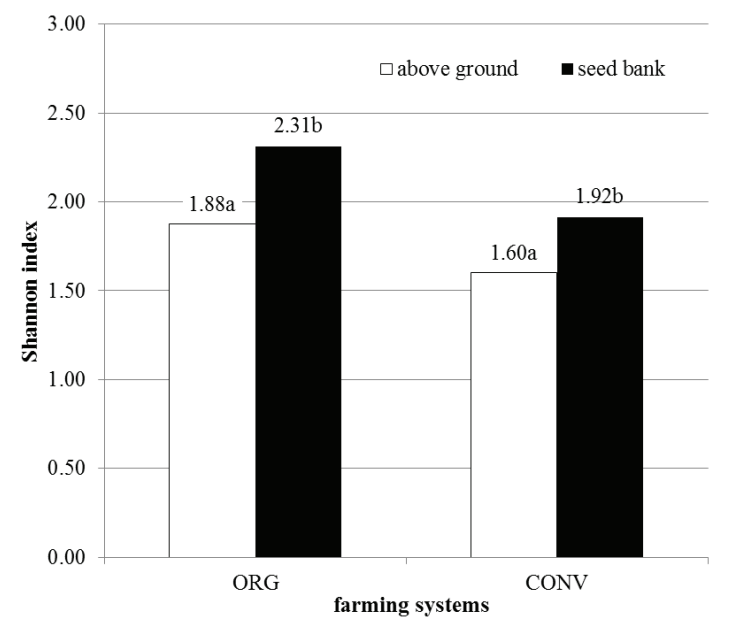

Figure 2. Shannon's diversity index of above ground-and soil seed bank weed communities (medians for the years 2012-2014).

$a, b$ - different letters indicate statistically significant differences between soil seed bank and above-ground weed communities.

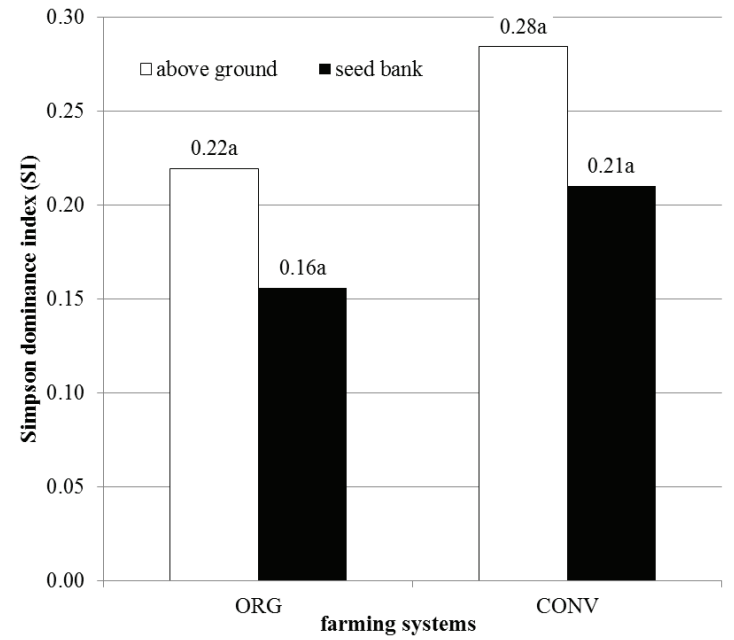

Figure 3. Simpson's dominance index of above ground-and soil seed bank weed communities (medians for the years 2012-2014).

a, $b$ - different letters indicate statistically significant differences between soil seed bank and above-ground weed communities.

the survival of species and stabilizes the agricultural ecosystem, as it is the 'evolutionary memory of fields', formed by a history much longer than the duration of the experiment (Simpson, Leck, \& Parker, 1989; Zanin, Mosca, \& Catizone, 1992; Radosevich, Holt, \& Ghersa, 1997; Doucet et al., 1999; Faist, Ferrenberg, \& Collinge, 2013; Vandvik et al., 2016).

\section{Above-ground and soil seed bank correlation}

The results of research showed a strong, positive correlation between above-ground and soil seed bank weed communities for most tested parameters (number of species, abundance of weeds/seeds, Shannon's diversity index, Simpson's dominance index) in both farming systems. Although the correlation occurred in both farming systems, it was stronger in the organic system than in conventional one (with the exception for the abundance of weeds and abundance of seeds correlation, where there were no correlation in organic farming system) (Table 2). Rahman, James \& Grbavac, (2006) also proved a strong linear relationship between the quantitative biodiversity of those two communities. Yasari \& Golafshan (2012) believe that the strength of the relationship between current weed infestation, visible in the field and the number of seeds accumulated in the soil also depends on the date of the test and it is higher at the beginning of vegetation, and then decreases.

Qualitative and quantitative similarity

Sorensen's qualitative similarity index for soil seed bank and above-ground weed flora for both farming systems showed that these weed communities were quite similar $(66.1 \%)$, while quantitative similarity 
Table 2

Spearman's correlation coefficient values $\left(R_{s}\right)$ for number of species, abundance of weeds and seeds, Shannon's diversity and Simpson's domination indices for organic and conventional farming system

\begin{tabular}{|l|c|c|}
\hline \multirow{2}{*}{ Correlation of soil seed bank and above ground weed communities } & \multicolumn{2}{c|}{ Farming system } \\
\cline { 2 - 3 } & organic & conventional \\
\hline Number of species & $0.66^{*}$ & $0.44^{*}$ \\
\hline Abundance & $-0,03$ & $0.45^{*}$ \\
\hline Shannon's index & $0.56^{*}$ & $0.46^{*}$ \\
\hline Simpson's index & $0.46^{*}$ & $0.38^{*}$ \\
\hline
\end{tabular}

*statistically significant correlations between soil seed bank and above-ground weed communities.

Quantitative and qualitative similarity indices (\%) of tested weed communities

\begin{tabular}{|c|c|c|c|c|c|c|c|c|}
\hline & & Quanti & e similar & ndex ( & & & & \multirow{8}{*}{$\begin{array}{c}\text { Quantitative similarity } \\
\text { index }(\%)\end{array}$} \\
\hline \multirow{8}{*}{$\begin{array}{l}\text { Qualitative } \\
\text { similarity } \\
\text { index (\%) }\end{array}$} & \multirow{2}{*}{\multicolumn{2}{|c|}{$\begin{array}{l}\text { Farming systems and } \\
\text { weed communities }\end{array}$}} & \multicolumn{2}{|c|}{ ORG } & \multicolumn{2}{|c|}{ CONV } & \multirow{2}{*}{$\begin{array}{l}\text { Seed } \\
\text { bank }\end{array}$} & \\
\hline & & & $\begin{array}{l}\text { Above } \\
\text { ground }\end{array}$ & Seed & $\begin{array}{l}\text { Above } \\
\text { ground }\end{array}$ & $\begin{array}{l}\text { Seed } \\
\text { bank }\end{array}$ & & \\
\hline & \multirow[t]{2}{*}{ ORG } & $\begin{array}{l}\text { Above } \\
\text { ground }\end{array}$ & $\times$ & 5.6 & 63.0 & 8.0 & \multirow{5}{*}{5.8} & \\
\hline & & Seed bank & 65.1 & $x$ & 4.0 & 70.2 & & \\
\hline & \multirow[t]{2}{*}{ CONV } & $\begin{array}{l}\text { Above } \\
\text { ground }\end{array}$ & 77.6 & 62.9 & $x$ & 6.1 & & \\
\hline & & Seed bank & 65.7 & 80.5 & 63.5 & $x$ & & \\
\hline & \multicolumn{2}{|c|}{ ABV.GROUND } & \multicolumn{4}{|c|}{66.1} & & \\
\hline & \multicolumn{8}{|c|}{ Qualitative similarity index (\%) } \\
\hline
\end{tabular}

was much lower $(5.8 \%)$, which resulted from much greater abundance of species in the soil seed bank (Table 3). Sorensen's coefficients also showed that both soil seed bank and the above-ground weed communities of the two tested farming systems had a relatively high level of similarity, both qualitative $(80.5 \%$ and $77.6 \%$, respectively) and quantitative (70.2\% and $63.0 \%$, respectively). Above-ground organic weed flora was at similar qualitative level of similarity to both organic and conventional soil seed bank (Sorensen's coefficient of about 65\%). At the same time, it was more similar to conventional above-ground flora (77.6\%). Correspondingly, above-ground conventional weed communities were qualitatively more similar to above-ground organic weed communities (77.6\%) than to both organic and conventional soil seed bank (qualitative similarity at a level of around 63\%). Hald (1999) found that the weed flora of organic fields is more similar to other organic fields than to conventional fields. In turn, the presented study shows that the observed qualitative composition of weed flora depends to a greater extent on the type of community (soil seed bank or aboveground weed community) than the farming system.

\section{Conclusions}

1. No significant differences were found in the number of weed species in the above-ground flora and soil seed bank.

2. Shannon's diversity index values were greater for soil seed bank than for above-ground weed flora in both farming systems, which indicates the importance of soil seed bank as a reservoir of biodiversity and 'evolutionary memory' of the agro-ecosystem.

3. Simpson's dominance index had lower values in the soil seed bank than above-ground weed community, which indicates that this community is less sensitive to dominance by a single species, which might be important for the ecological stability of agro-ecosystem.

4. Above-ground and soil seed bank weed communities are closely related to each other, which was proven by strong, positive correlation of the number of species, Shannon's diversity index and Simpson's dominance index for those two communities.

5. Sorensen's qualitative coefficient showed a greater similarity within the tested communities (above- 
ground and soil seed bank) than within farming systems (organic and conventional).

6. Qualitative similarity (species) of both weed communities and both farming systems was generally higher than quantitative similarity (abundance).

\section{Acknowledgements}

The study was conducted within $\mathrm{KIK} / 25$ project. The presented paper was developed within the 1.3 task of Multiannual Programme of Institute of Soil Science and Plant Cultivation, State Research Institute in Puławy, Poland.

\section{References}

1. Baker, H.G. (1989). Some aspects of the natural history of seed banks. In Leck, M.A., Parker, V.T., \& Simpson R.L. (Eds.). Ecology of Soil Seed Banks (pp. 5-19). London: Academic Press.

2. Cavers, P.B. (1983). Seed demography. Canadian Journal of Botany, 61(12), 3578-3590.

3. Chick, M.P., Nitschke, C.R., Cohn, J.S., Penman, T.D., \& York, A. (2018). Factors influencing aboveground and soil seed bank vegetation diversity at different scales in a quasi-Mediterranean ecosystem. Journal of Vegetation Science, 29(4), 684-694. DOI: 10.1111/jvs.12649.

4. Clergue, B., Amiaud, B., Pervanchon, F., Lasserre-Joulin, F., \& Plantureux, S. (2005). Biodiversity: function and assessment in agricultural areas. A review. Agronomy for Sustainable Development, 25(1), 1-15. DOI: 10.1051/agro: 2004049.

5. Doucet, C., Weaver, S.E., Hamill, A.S., \& Zhang, J. (1999). Separating the effects of crop rotation from weed management on weed density and diversity. Weed Science, 47, 729-735.

6. European Commission. (2011). The EU Biodiversity Strategy to 2020. Publications Office of the European Union. DOI: $10.2779 / 39229$.

7. Faist, A.M., Ferrenberg, S., \& Collinge, S.K. (2013). Banking on the past: seed banks as a reservoir for rare and native species in restored vernal pools. AoB Plants, 5, 1-11. DOI: 10.1093/aobpla/plt043.

8. Feledyn-Szewczyk, B. (2003). Oddziatywanie systemu produkcji na skład gatunkowy chwastów w pszenicy ozimej $i$ glebowy bank nasion (The impact of the production system on the species composition of weeds in winter wheat and the soil seed bank). Unpublished doctoral dissertation, Puławy, Poland. (in Polish)

9. Feledyn-Szewczyk, B., \& Duer, I. (2007). Podobieństwo glebowego banku nasion i aktualnego zachwaszczenia łanu pszenicy ozimej w różnych systemach produkcji rolnej (Similarity between soil seed bank and current weed flora in winter wheat cultivated in different crop production systems). Annales Universitatis Mariae Curie-Skłodowska Lublin - Polonia. Sectio E, Agricultura, 62(2), 157-167. (in Polish)

10. Froud-Williams, R.J., Chancellor, R.J., \& Drennan, D.S.H. (1983). Influence of cultivation regime upon buried weed seeds in arable cropping systems. Journal of Applied Ecology, 20, 199-208.

11. Graziani, F., Onofri, A., Pannacci, E., Tei, F., \& Guiducci, M. (2012). Size and composition of weed seedbank in long-term organic and conventional low-input cropping systems. European Journal of Agronomy, 39, 52-61. DOI: 10.1016/j.eja.2012.01.008.

12. Hald, A.B. (1999). Weed vegetation (wild flora) of long established organic versus conventional cereal fields in Denmark. Annals of Applied Biology, 134(3), 307-314.

13. Harper, J.L. (1977). Population biology of plants. pp. 892.

14. Murphy, S.D., Clements, D.R., Belaoussoff, S., Kevan P.G., \& Swanton, C.J. (2006). Promotion of weed species diversity and reduction of weed seedbanks with conservation tillage and crop rotation. Weed Science 54(1), 69-77. DOI: 10.1614/WS-04-125R1.1

15. Pawłowski, F., \& Wesołowski, M. (1980). Zasób i skład gatunkowy nasion chwastów w różnych kompleksach gleb w południowo-wschodniej Polsce (Abundance and species composition of weed seeds in various soil complexes in the south-eastern Poland). Roczniki Nauk Rolniczych, seria A, 104(4), 87100. (in Polish)

16. Pawłowski, F., \& Wesołowski, M. (1989). Poziom agrotechniki a plonowanie i zachwaszczenie roślin w zmianowaniu na glebie lessowej. Cz. III.: Zachwaszczenie gleby (The level of agrotechnology and its impact on yielding and weed infestation in different crop rotations on the loess soils. Vol. III: Weed infestation). Roczniki Nauk Rolniczych, seria A, 108(4), 157-169. (in Polish)

17. Radosevich, S., Holt, J., \& Ghersa, C. (1997). Weed ecology: implications for management. John Wiley and Sons.

18. Rahman, A., James, T.K., \& Grbavac, N. (2006). Correlation between the soil seed bank and weed populations in maize fields. Weed Biology and Management 6(4), 228-234. DOI: 10.1111/j.14456664.2006.00223.x. 
19. Simpson, R.L., Leck, M.A., \& Parker, V.T. (1989). Seed Banks: General Concepts and Methodological Issues. In Leck, M.A., Parker, V.T., \& Simpson, R.L. Ecology of Soil Seed Banks (pp. 3-8). London: Academic Press.

20. Teasdale, J.R., Mangum, R.W., Radhakrishnan, J., \& Cavigelli, M.A. (2004). Weed seedbank dynamics in three organic farming crop rotations. Agronomy Journal, 96(5), 1429-1435. DOI: 10.2134/agronj2004.1429.

21. Turner, R.J., Davies, G., Moore, H., Grundy, A.C., \& Mead, A. (2007). Organic weed management: a review of the current UK farmer perspective. Crop Protection, 26, 377-382. DOI: 10.1016/j.cropro.2006.01.021.

22. Vandvik, V., Klanderud, K., Meineri, E., Måren, I.E., \& Töpper, J. (2016). Seed banks are biodiversity reservoirs: species-area relationships above versus below ground. Oikos, 125(2), 218-228. DOI: 10.1111/ oik.02022.

23. Vandvik, V., Klanderud, K., Meineri, E., Måren, I.E., \& Töpper, J. (2016). Seed banks are biodiversity reservoirs: species-area relationships above versus below ground. Oikos, 125(2), 218-228 DOI: 10.1111/ oik.02022.

24. Wesołowski, M. (1984). Zawartość nasion chwastów w ważniejszych glebach makroregionu południowowschodniego i środkowego Polski (The content of weed seeds in the most important soils of the southeastern and central Poland macroregion). Roczniki Nauk Rolniczych, seria A, 106(1), 169-183. (in Polish)

25. Woch, M.W. (2012). Trwałość glebowego banku nasion krótkotrwałej roślinności synantropijnej na terenach współcześnie opuszczonych osad (Persistence of soil seed bank of short-living synanthropic vegetation in contemporary abandoned settlements). Acta Botanica Silesiaca, 6, 143-155. (in Polish)

26. Wojciechowski, W., \& Sowiński, J. (2007). Wpływ sposobu zagospodarowania pól na zapas diaspor chwastów w glebie (The effect of field management on weed seed bank in the soil). Annales UMCS Lublin - Polonia, Sectio E, Agricultura, 62(2), 33-39. (in Polish)

27. Yasari, E., \& Golafshan, M.G. (2012). Study of the Spatial Relationship between Seed Bank and Weed Populations and the Distribution Pattern of Weeds in Corn Fields during the Growing Season. International Journal of Biology, 4(4), 101-110.

28. Zanin, G., Mosca, G., \& Catizone, P. (1992). A profile of the potential flora in maize fields of the Po Valley. Weed Research, 32, 407-418.

29. Zhang, J., Hamill, A.S., Gardiner, I.O., \& Weaver, S.E. (1998). Dependence of weed flora on the active soil seedbank. Weed Research, 38, 143-152. 